\title{
System Usability Scale Antarmuka Palembang Guide Sebagai Media Pendukung Asian Games XVIII
}

\author{
Usman Ependi $^{1)}$, Febriyanti Panjaitan ${ }^{2)}$, Hutrianto ${ }^{3)}$ \\ ${ }^{1,2,3}$ Program Studi Teknik Informatika, Fakultas Ilmu Komputer, Universitas Bina Darma \\ Jl Jendral Ahmad Yani No 3 Plaju, Palembang \\ ${ }^{1)}$ u.ependi@binadarma.ac.id \\ ${ }^{2)}$ febriyanti.panjaitan@binadarma.ac.id \\ ${ }^{3)}$ hutrianto@binadarma.ac.id
}

\begin{abstract}
Abstrak - Palembang Guide merupakan perangkat lunak penyedia informasi sarana pendukung pelaksanaan Asian Games XVIII yang berisikan informasi venue olahraga, fasilitas transportasi, objek wisata, restoran, toko (mall), hotel, tempat pengisian bahan bakar, fasilitas kesehatan, pos kemanan, kantor pemerintahan dan institusi pendidikan. Perangkat lunak ini dikembangkan sesuai dengan instruksi presiden Republik Indonesia tentang persiapan pelaksanaan Asian Games tahun 2018. Untuk menjamin perangkat lunak Palembang Guide layak untuk digunakan oleh pengguna akhir maka dilakukan pengujian antarmuka menggunakan instrumen system usability scale (SUS). Pengujian antarmuka dengan instrumen $S U S$ telah dilakukan secara terstruktur dan terukur secara akurat menggunakan 10 pernyataan sebagai tolak ukur penilaian. Hasil pengujian antarmuka perangkat lunak Palembang Guide dengan instrumen SUS memperlihatkan skor penilaian berada pada angka 83 yang berarti perangkat lunak Palembang Guide dinyatakan dapat diterima (acceptable) dan termasuk dalam grade A dan B dengan rating excellent. Dengan demikian perangkat lunak Palembang Guide dapat dijadikan salah satu alternative alat bantu bagi masyarakat dalam mencari tempat tempat sarana prasarana pendukung yang dibutuhkan berkaitan dengan Asian Games XVIII di Kota Palembang.
\end{abstract}

\section{Kata Kunci-System Usability Scale, Antarmuka, Asian Games XVIII}

Abstract - Palembang Guide is software that providing information for supporting Asian Games XVIII which contains information about sports venues, transportation facilities, tourist destination, restaurants, store (malls), hotels, refueling station, hospital, police, offices, and education. Palembang Guide is developed based on the presidential instruction of the Republic of Indonesia on preparations for the Asian Games 2018. To ensure the Palembang Guide is feasible to be used by users, it needs to test using usability scale instrument (SUS).Testing Palembang Guide interface with SUS instrument has been done in a structured and accurately measured using 10 statements as a benchmark assessment. The Palembang Guide interface test result with SUS instrument shows the scoring score is at number 83 that means Palembang Guide is declared acceptable and classified into grade $A$ and $B$ with an excellent rating. Based on the testing result of Palembang Guide can be used as an alternative tool for the community in searching for supporting infrastructure related to Asian Games XVIII in Palembang.

\section{Keywords-System Usability Scale, Interface, Asian Games XVIII}

Article history:

Received 20 April 2017; Received in revised form 21 July 2017; Accepted 1 August 2017; Available online 28 October 2017

\section{PENDAHULUAN}

Asian Games adalah ajang olahraga yang diselenggarakan setiap empat tahun. Negara peserta Asian games adalah semua negera-negara asia yang berjumlah empat puluh lima (45) negara. Pada tahun 2018 Indonesia berkesampatan menjadi tuan rumah penyelengaraan Asian Games yang ke XVIII. Penyelengaraan tersebut dipusatakan menjadi dua provinsi yaitu Provinsi Khusus Ibukota Jakarta dan Provinsi Sumatera Selatan. Sesuai dengan Intruksi Presiden Republik Indonesia Nomor 2 Tahun 2016 tentang dukungan penyelenggaraan Asian Games XVIII tahun 2018 maka harus dibuat persiapan yang matang dari segala lini untuk mencapai kesuksesan penyelengaraan Asian Games. Instruksi tersebut diberikan kepada dua puluh delapan (28) pihak terkait mulai dari kementrian, pimpinan lembaga tinggi negara dan guburnur.

Salah satu isi instruksi Presiden Republik Indonesia nomor 2 tahun 2016 yaitu instruksi kepada menteri komunikasi dan informatika berupa memfasilitasi perijinan untuk broadcast, menyediakan media center, jaringan internet, solusi teknologi informasi (information technology solution) dan melaksanakan sosialisasi. Sedangkan instruksi Presiden Republik Indonesia kepada Guburnur Sumatera Selatan sebagai salah satu tempat pelaksanaan Asian Games adalah membangun dan menyiapkan kampung atlet (athlete village) maupun merenovasi infrastruktur dan sarana pendukung lainnya; serta merencanakan, mempersiapkan, melaksanakan pembangunan seluruh fasilitas dan harus 
berkoordinasi dengan Panitia Nasional INASGOC dan Kementerian Pemuda dan Olahraga.

Melihat kondisi tersebut maka salah satu upaya untuk melaksanakan isi instruksi presiden dapat dilakukan dengan cara menerapakan teknologi informasi dan komuniskasi (TIK). Penerapan TIK dapat dilakukan dengan cara membangun media pendukung pelaksanaan kegiatan Asian Games XVIII berupa perangkat yang dapat memandu pengunjung baik nasional maupun internasional sebagai alat bantu berupa perangkat lunak Palembang Guide. Perangkat lunak Palembang Guide merupakan penyedia informasi sarana pendukung pelaksanaan Asia Games seperti venue olahraga, fasilitas transportasi, objek wisata, restaurant, tempat hiburan (mall), hotel, tempat pengisian bahan bakar, fasilitas kesehatan, pos kemanan, kantor pemerintahan dan institusi pendidikan. Penyediaan informasi sarana pendukung pelaksanaan Asian Games XVIII menjadi sangat penting mengingat beberapa hal: Kota Palembang saat ini tidak memiliki media penyebar informasi yang dikhususkan berkaitan dengan tempat tempat sarana pendukung Asian Games XVIII; Kebutuhan masyarakat baik lokal, nasional dan internasional akan informasi sarana dan prasarana pelaksanaan Asian Games yang dapat diakses dan digunakan secara mudah. Sehingga adanya informasi yang memadai berkaitan dengan sarana pendukung pelaksanaan Asian Games Ke XVII maka para atlet dan wisatawan dapat dengan mudah mengenal dan mejelajahi tempat tempat yang ada di Kota Palembang.

Selan itu juga dukungan TIK secara umum dapat diartikan sebagai teknologi yang berhubungan dengan pengambilan, pengumpulan, pengolahan, penyimpanan, penyebaran, dan penyajian informasi (Asmani, 2011). TIK mencakup dua aspek perpaduan yang tidak terpisahkan yaitu teknologi informasi dan teknologi komunikasi. Teknologi informasi meliputi segala hal yang berkaitan dengan proses, penggunaan sebagai alat bantu, manipulasi, dan pengelolaan informasi. Sedangkan teknologi komunikasi berkaitan dengan penggunaan alat bantu untuk memproses dan mentransfer data dari perangkat satu ke perangkat yang lainnya. Untuk itu sebelum perangkat lunak Palembang Guide yang berisikan informasi tentang sarana dan prasarana pendukung Asian Games XVIII digunakan secara luas oleh pengguna akhir maka perlu untuk dipastikan atau dilakukan pengujian terhadap perangkat lunak agar dapat digunakan dengan mudah dan memiliki nilai kebergunaan yang tinggi, Salah satu upaya yang dapat dilakukan untuk memastikan bahwa perangkat lunak Palembang Guide memiliki antarmuka yang user friendly maka dapat dilakukan pengukuran antarmuka yang dilihat dari sisi pengguna akhir.
Dengan dilakukan pengukuran antarmuka maka dapat diketahui secara umum bagaimana penilaian pengguna terhadap perangkat lunak Palembang Guide sebagai bahan evaluasi jika akan dilakukan perbaikan sebelum dipublikasi.

Untuk melakukan pengujian antarmuka memiliki berbagai metode yang dapat digunakan diantaranya adalah heuristic evaluation (HE) dan system usability scale (SUS). Heuristic evaluation (HE) dan system usability scale (SUS) merupakan bagian dari pengujian usability. Fokus dari kedua metode pengujian tersebut sama sama menilai interaksi antarmuka perangkat lunak, namun yang membedakan keduanya terletak pada penguji (evaluator). Heuristic evaluation (HE) pengujian antarmuka yang dilakukan oleh ahli (expert) (Hadi, 2010) sedangkan system usability scale (SUS) pengujian antarmuka yang dilakukan langsung oleh pengguna akhir (end user) (Martoyo \& Falahah, 2015). Untuk itu dalam melakukan pengujian perangkat lunak Palembang Guide digunakan system usability scale (SUS) sebagai instrumen pengujian. Penggunaan SUS sendiri karena dalam melakukan pengujian lebih menekankan perspektif pengguna akhir sehingga hasil evaluasi akan lebih sesuai dengan keadaan nyata. Pengujian SUS memiliki 10 pernyataan sebagai alat pengujian, $S U S$ juga tidak memerlukan jumlah sampel yang banyak sehingga dapat meminimalisir biaya pengujian (Brooke, 1996).

Pengujian SUS juga telah dilakukan pada aplikasi kepegawaian Dinas Peternakan Kabupaten Bandung. Pada pengujian tersebut digunakan 5 (lima) responden sebagai sampel uji. Diperoleh hasil bahwa apliaksi kepegawaian tersebut mendapatkan index B dan dapat diterapkan (Pudjoatmodjo \& Wijaya, 2016). Dengan demikian diharapkan pengujian perangkat lunak Palembang Guide dengan pemanfaatan instrument SUS akan mendapatkan hasil pengujian yang akurat.

\section{Metode Penelitian}

Untuk mendapatkan hasil penelitian yang benar dan akurat, maka metode penelitian yang digunakan dalam melakukan penilaian perangkat lunak Palembang Guide dapat dijelaskan sebagai berikut:

\section{A. Metode Penelitian}

Metode penelitian yang digunakan dalam penelitian ini adalah metode deskriptif. Dimana penelitian deskriptif adalah suatu bentuk penelitian yang ditujukan untuk mendeskripsikan fenomenafenomena yang ada, baik fenomena alamiah maupun fenomena buatan manusia. Fenomena itu berupa bentuk, aktivitas, karakteristik, perubahan, hubungan, kesamaan, dan perbedaan antara fenomena yang satu denganfenomena lainnya 


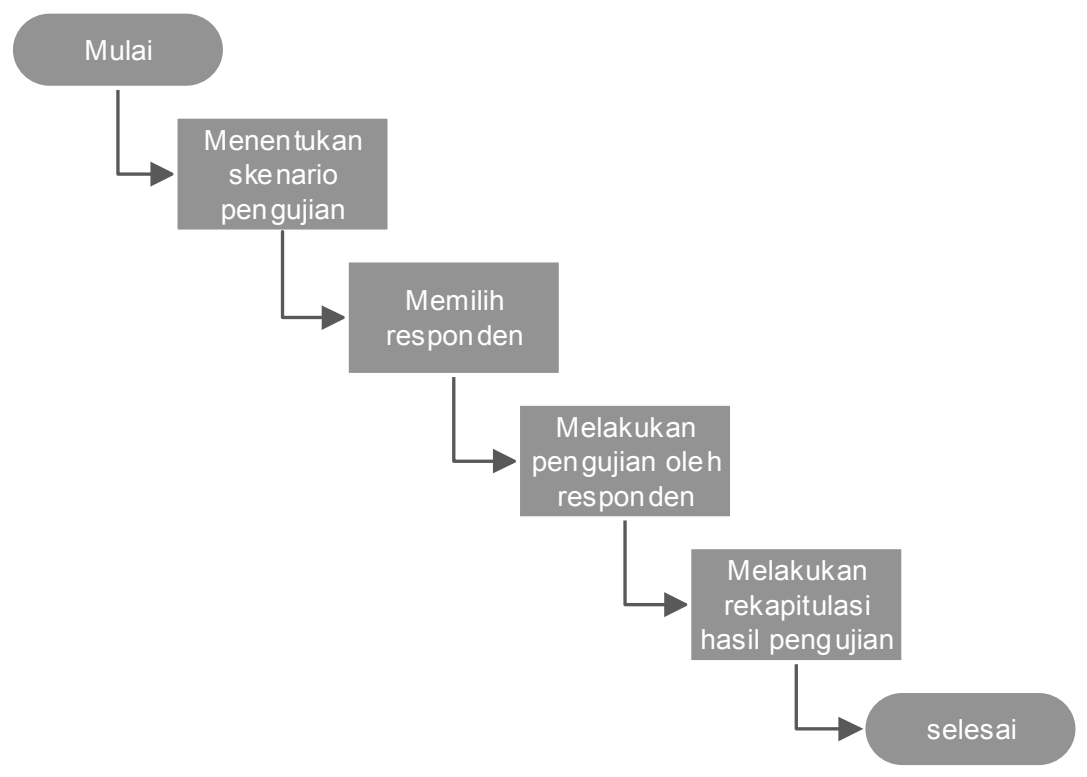

Gambar 1. Langkah Langkah Penelitian

TABel1. InStRument PENGUJiAn SUS

\begin{tabular}{|c|c|c|}
\hline No & Pernyataan & Skala \\
\hline 1 & $\begin{array}{l}\text { I think that I would like to use this system frequently } \\
\text { (Saya pikir bahwa saya akan ingn lebih sering menggunakan aplikasi ini) }\end{array}$ & $1 \mathrm{~s} / \mathrm{d} 5$ \\
\hline 2 & $\begin{array}{l}\text { Ifound the system unnecessarily complex. } \\
\text { (Saya meemukan bahwa aplikasi ini, tidak harus dibuat serumit ini) }\end{array}$ & $1 \mathrm{~s} / \mathrm{d} 5$ \\
\hline 3 & $\begin{array}{l}\text { I thought the system was easy to use } \\
\text { (Saya pikir aplikasi mudah untuk digunakan) }\end{array}$ & $1 \mathrm{~s} / \mathrm{d} 5$ \\
\hline 4 & $\begin{array}{l}\text { I think that I would need the support of a technical person to be able to use this system. } \\
\text { (Saya pikir bahwa saya akan } \\
\text { membutuhkan bantuan dari orang teknis untuk dapat menggunakan aplikasi ini) }\end{array}$ & $1 \mathrm{~s} / \mathrm{d} 5$ \\
\hline 5 & $\begin{array}{l}\text { I found the various functions in this system were well integrated } \\
\text { (Saya meneukan berbagai fungsi di aplikasi ini diintegrasikan dengan baik) }\end{array}$ & $1 \mathrm{~s} / \mathrm{d} 5$ \\
\hline 6 & $\begin{array}{l}\text { I thought there was too much inconsistency in this system } \\
\text { (Saya pikir ada terlalu banyak ketidaksesuaian dalam aplikasi ini) }\end{array}$ & $1 \mathrm{~s} / \mathrm{d} 5$ \\
\hline 7 & $\begin{array}{l}\text { I would imagine that most people would learn to use this system very quickly } \\
\text { (Saya bayangkan bahwa kebanyakan orang akan mudah untuk mempelajari aplikasi ini dengan sangat } \\
\text { cepat) }\end{array}$ & $1 \mathrm{~s} / \mathrm{d} 5$ \\
\hline 8 & $\begin{array}{l}\text { I found the system very cumbersome to use } \\
\text { (Saya menemukan, aplikasi ini sangat rumit untuk digunakan) }\end{array}$ & $1 \mathrm{~s} / \mathrm{d} 5$ \\
\hline 9 & $\begin{array}{l}\text { I felt very confident using the system } \\
\text { (Saya merasa sangat percaya diri untuk menggunakan aplikasi ini) }\end{array}$ & $1 \mathrm{~s} / \mathrm{d} 5$ \\
\hline 10 & $\begin{array}{l}\text { I needed to learn a lot of things before I could get going with this system } \\
\text { (Saya perlu belajar banyak hal sebelum saya bisa memulai menggunakan aplikasi) }\end{array}$ & $1 \mathrm{~s} / \mathrm{d} 5$ \\
\hline
\end{tabular}

(Mustami, 2016). Adapun langkah penelitian ini diperlihatkan pada Gambar 1.

Gambar 1 memperlihatkan langkah-langkah penelitian yang dimulai dengan menentukan skenario pengujian, memilih responden, melakukan pengujian oleh responden dan melakukan rekapitulasi hasil pengujian. Pada langkah menentukan skenario pengujian pekerjaan yang dilakukan adalah membuat skenario pengujian yang dimulai dengan menjelaskan perangkat lunak yang akan diuji dan kuisioner. Pada langkah memilih responden pekerjaan yang dilakukan adalah menentukan responden yang akan menilai perangkat lunak palembang guide. Pada langkah melakukan pengujian pekerjaan yang dilakukan adalah meminta responden memberikan penilaian terhadap perangkat lunak Palembang Guide berdasarkan instrumen SUS. Langkah terakhir adalah melakukan rekapitulasi hasil pengujiandimana pada langkah ini proses rekapitulasi dihitung sesuai dengan perhitungan SUS dan hasil pengujian didapat.

\section{B. Metode Pengujian}

Dalam melakukan pengujian antarmuka perangkat lunak Palembang Guide metode yang digunakan adalah system usability scale (SUS). SUS dapat digunakan dalam melakukan pengujian teknologi yang independen baik pada perangkat keras, perangkat lunak, website dan bahkan perangkat seluler (Sauro, 2011). Dalam melakukan pengujian SUS memiliki 10 (sepuluh) instrumen seperti yang terlihat pada Tabel 1 .

Dari Tabel 1 dapat dijelaskan bahwa skala pengujian antarmuka perangkat lunak Palembang Guide dimulai dari 1 sampai dengan 5, yang 
berarti 1 sangat tidak setuju dan 5 sangat setuju terhadap pernyataan instrumen $S U S$.

\section{Metode Perhitungan Skor SUS}

Perhitungan hasil pengujian perangkat lunak Palembang Guide dengan instrument SUS dilakukan dengan mengikuti beberapa aturan sebagai berikut: Setiap penyataan dengan nomor ganjil maka skala jawaban responden dikurangi 1 . Setiap pernyataan dengan nomor genap maka 5 dikurangi skala jawaban responden. Hasil nilai skala 0 sampai dengan 4 (empat menjadi respon paling positif). Menjumlahkan skala jawaban responden dan dikali 2.5. Menentukan rata rata jawaban semua responden.

\section{HASIL DAN PEMBAHASAN}

Hasil penelitian setelah melalui langkah-langkah penelitian seperti yang diperlihatkan pada Gambar 1 maka dapat dijelaskan sebagai berikut:

\section{A. Perangkat Lunak Palembang Guide}

Perangkat lunak Palembang Guide merupakan objek penilaian dengan instrumen SUS, dimana perangkat lunak ini memiliki fungsi utama sebagai petunjuk pencarian tempat di Kota Palembang dalam upaya penyediaan informasi pendukung pelaksanaan Asian Games XVIII.Tampilan utama perangkat lunak Palembang Guide seperti yang terlihat pada Gambar 2.

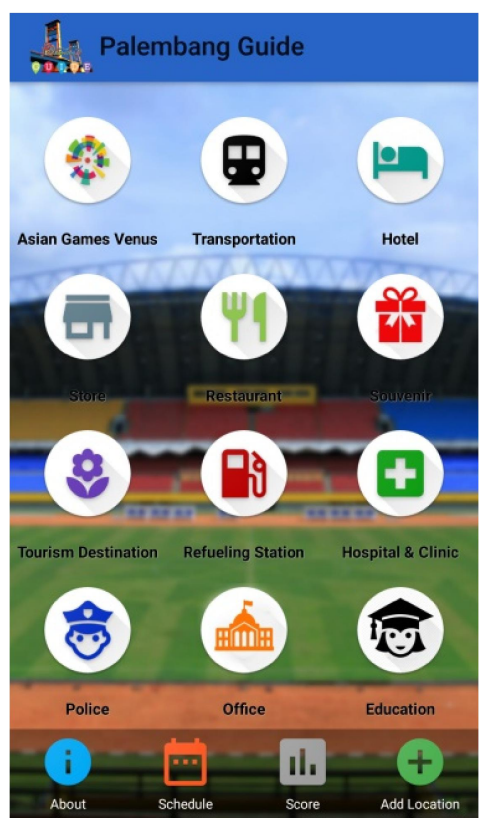

Gambar 2. Tampilan Palembang Guide

Perangkat lunak Palembang Guide seperti pada Gambar 2 memiliki 12 (dua belas) menu utama yaitu Asian games venue, transportation, hotel, store, restaurant, souvenir, tourism destination, gas station, hospital \& clinic, policestation, office dan educationdan empat menu tambahan yaitu about, schedule, score dan add location. Ketika salah satu menu pencarian tempat diklik, maka otomatis perangkat lunak Palembang Guide akan menampilkan semua tempat sesuai dengan kategori.

Dari tempat yang ditampilkan sesuai kategori maka pengguna dapat memberi rating tempat dan melihat rute perjalanan seperti yang diperlihatkan pada Gambar 3.

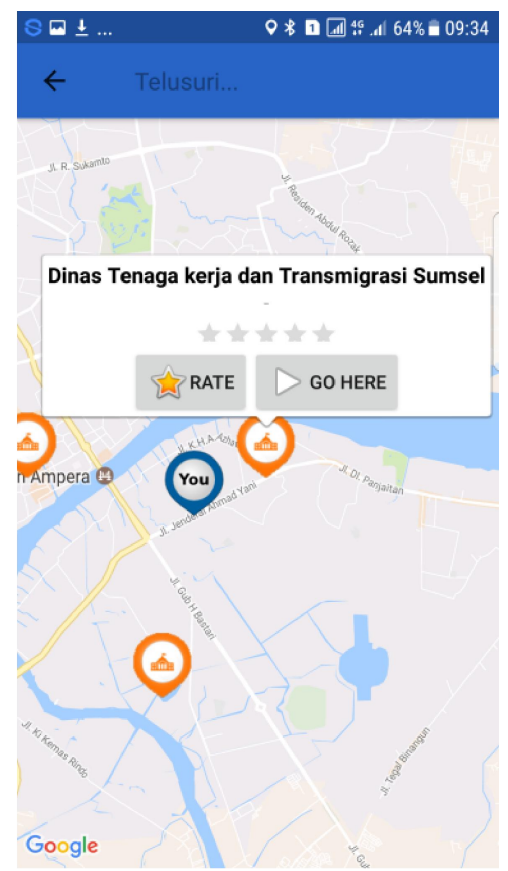

Gambar 3. Pilihan aksi bagi pengguna ketika klik tempat

Ketika pengguna melihat detail tempat dengan cara mengklik icon tempat, maka otomatis akan tampil halaman rating. Selanjutnya, pengguna dapat memberikan rating tempat dan komentar tentang tempat seperti yang diperlihatkan pada Gambar 4.
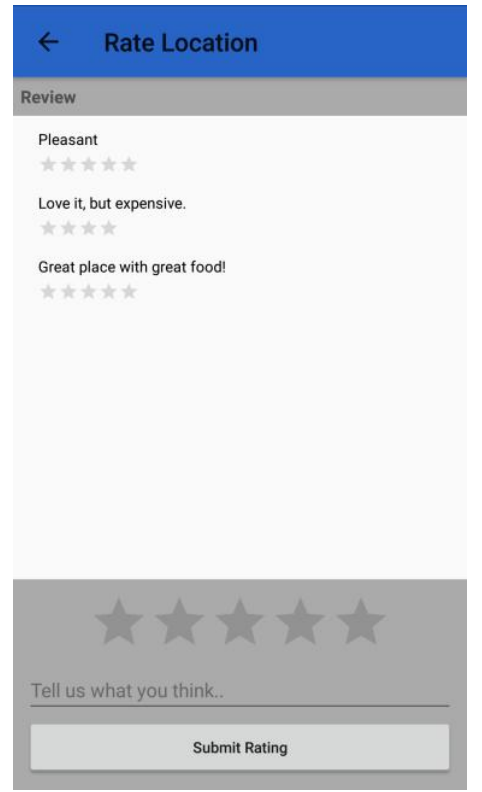

Gambar 4. Pemberian rating dan komentar tempat

Selain itu pengguna juga dapat melihat rute pejalan dengan cara mengklik go here. Ketika 
pengguna mengklik go here, maka otomatis akan ditampilkan rute perjalanan ke tempat yang dilihat (Gambar 5).

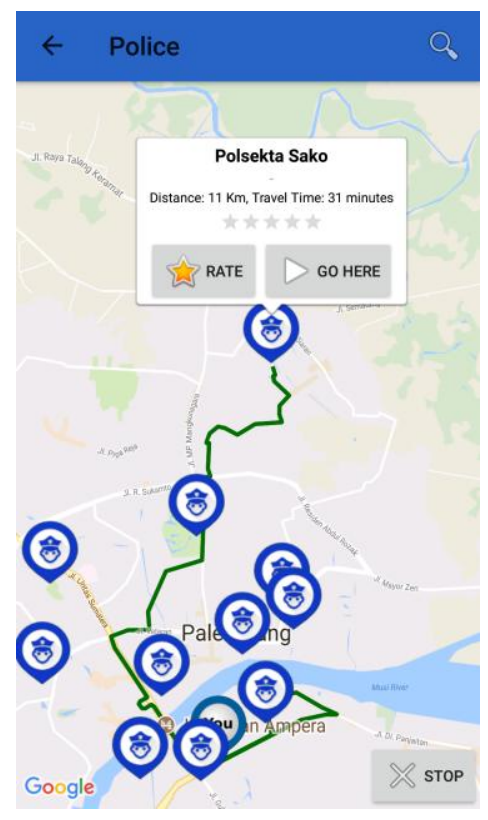

Gambar 5. Rute Perjalanan

Selain dari fungsi utama dalam memberikan petunjuk arah ke tempat tempat sesuai kategori Palembang Guide memiliki fitur pencarian tempat sesuai kategori, informasi jadwal pertandingan Asian Games XVIII, skor klasemen Asian Games XVIII dan penambahan lokasi oleh pengguna sesuai dengan 12 kategori yang disediakan.

\section{B. Responden}

Responden dalam pengujian dengan instrument SUS terdiri dari 5 (lima) responden (Pudjoatmodjo $\&$ Wijaya, 2016). Namun untuk mendapatkan data yang lebih akurat maka reponden pengujian perangkat lunak Palembang Guidedilipatgandakan menjadi 10 responden. Karateristik responden terdiri dari jenis kelamin, tingkat pendidikan, pengalaman menggunakan smartphone dan usia.Untuk karateristik jenis kelamin responden yang memberikan penilaian terdiri dari 5 (lima) respoden dengan jenis kelamin laki-laki dan 5 (lima) respoden dengan jenis kelamin perempuan. Sedangkan tingkat pendidikan master 5responden, sarjana 2 responden, SMA (mahasiswa) 3 reponden. Pengalaman respoden menggunakan smartphone telah lebih dari 5 (lima) tahun untuk semua responden. Sedangkan umur responden diantara $17 \mathrm{~s} / \mathrm{d} 20$ tahun 3 responden, $21 \mathrm{~s} / \mathrm{d} 25$ tahun 2 responden, $26 \mathrm{~s} / \mathrm{d} 30$ tahun 3 responden, dan $30 \mathrm{~s} / \mathrm{d} 40$ tahun 2 responden.

Reponden yang memberikan penilaian terhadap perangkat lunak Palembang Guide dapat mewakili pengguna akhir yang terdiri dari pengunjung dan masyarakat Kota Palembang ketika pelaksanaan Asian Games XVIII. Dimana responden tersebut mewakili pengguna akhir dengan tingkat pendidikan mulai dari SMA hingga master dengan umur mulai dari $17 \mathrm{~s} / \mathrm{d} 40$ tahun dan jenis kelamin antara laki-laki dan perempuan yang simbang serta pengalaman penggunaan smartphone lebih dari 5 tahun. Dengan demikian keterwakilan semua kelompok pengguna baik dari tingkat pendidikan, usia, jenis kelamin mapun pengalaman dalam menggunakan smartphone dapat dilihat secara nyata dan objektif dari karateristik responden tersebut.Selain itu juga pemilihan jumlah responden dan karateristik responden tersebut dapat menggambarkan keadaan pengguna akhir yang akan memanfaatkan perangkat lunak Palembang Guide karena telah mewakili dari masing masing karateristik pengguna akhir.

\section{Hasil Penilaian Responden}

Hasil penilaian responden dapat dilihat pada Tabel 2. Dimana nilai skala akhir didapat berdasarkan aturan metode Perhitungan Skor SUS. Hasil penilaian responden terhadap perangkat lunak Palembang Guide sebagai sarana penunjang penyediaan informasi pelaksanaan Asian Games XVIII dapat dilihat seperti pada Tabel 2.

TABel 2.HASIL PENILAIN RESPONDEN

\begin{tabular}{ccc}
\hline \hline Responden & Hasil Penilaian & Skor \\
\hline $\mathbf{1}$ & $36 \times 2.5$ & 90 \\
$\mathbf{2}$ & $31 \times 2.5$ & 77.5 \\
$\mathbf{3}$ & $32 \times 2.5$ & 80 \\
$\mathbf{4}$ & $34 \times 2.5$ & 85 \\
$\mathbf{5}$ & $35 \times 2.5$ & 87.5 \\
$\mathbf{6}$ & $35 \times 2.5$ & 87.5 \\
$\mathbf{7}$ & $32 \times 2.5$ & 80 \\
$\mathbf{8}$ & $32 \times 2.5$ & 80 \\
$\mathbf{9}$ & $33 \times 2.5$ & 82.5 \\
$\mathbf{1 0}$ & $32 \times 2.5$ & 80 \\
& Rerata & $830 / 10=\mathbf{8 3}$ \\
\hline \hline
\end{tabular}

Selanjutnya adalah menentukan nilai rata-rata dari penilaianan responden. Dimana dari 10 (sepuluh) responden didapat jumlah nilai sebesar 830 (delapan ratus tiga puluh) dan dibagi 10 (sepuluh)maka didapat nilai rata-rata sebesar 83 (delapan puluh tiga). Setelah mendapatkan hasil akhir penilaian responden maka selanjutnya adalah menentukan grade hasil penilaian. Untuk menentukan grade hasil penilaian ada 2 (dua)cara yang dapat digunakan (Brooke, 2013). Penentuan pertama dilihat dari sisi tingkat penerimaan pengguna, grade skala dan adjektif rating yang terdiri dari tingkat penerimaan pengguna terdapat tiga kategori yaitu not acceptable, marginal dan acceptable.Sedangakan dari sisi tingkat grade skala terdapat enam skala yaitu A, B, C, D, E dan F.dan dari adjektif rating terdiri dari worst imaginable, poor, ok, good, excellent dan best imaginable seperti yang diperlihatkan pada Gambar 6 . 


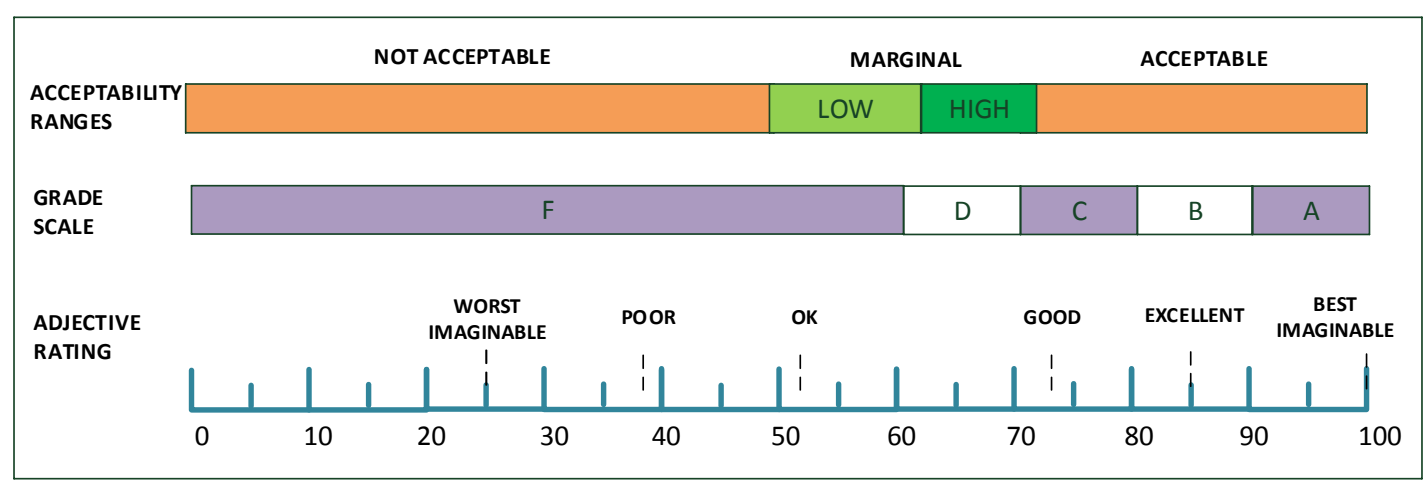

Gambar 6. Penentuan Hasil Penilaian (Bangor, Kortum, \& Miller, 2009)

Penentuan yang kedua dilihat dari sisi percentile range (SUS skor)yang memiliki grade penilaian yang terdiri dari A, B, C, D dan F. Dari dua cara penentuan hasil penilaian tersebut maka dapat dilihat hasil penilaian sebagai berikut:

1)Acceptability, Grade Scale, Adjective Rating : Penentuan Acceptability, grade scale, adjective rating digunakan untuk melihat sejauh mana perspective pengguna terhadap perangkat lunak Palembang Guide. Untuk menentukan Acceptability, grade scale, adjective rating maka dilakukan perbandingan hasil penilaian rata-rata responden sebesar 83 (delapan puluh tiga) dengan ketentuan penilaian seperti Gambar 6. Untuk itu dari hasil penilaian yang diberikan responden maka hasil penilaian terhadap perangkat lunak Palembang Guide sebagai berikut: a) Tingkat penerimaan pengguna masuk dalam kategori acceptable, b) Tingkat grade skala masuk dalam kategori B, dan c) Adjektif rating masuk dalam kategori excellent. Sesuai dengan hasil penilaian tersebut maka perangkat lunak Palembang Guide dapat digunakan dengan mudah oleh pengguna akhir dan dapat juga dijadikan sebagai alat pendukung penyedia informasi tempat tempat sarana dan prasarana pelaksanaan Asia Games seperti venue olahraga, transportasi, objek wisata, resoran, toko (mall), hotel, tempat pengisian bahan bakar, fasilitas kesehatan, pos kemanan, kantor dan institusi pendidikan.

2) SUS Skor percentile rank: Penentuan hasil penilaian dengan cara SUS skor percentile rank memiliki perbedaan dengan cara penilaian Acceptability, grade scale, adjective rating. Perbedaan yang terjadi pada kategori penilaian, pada SUS skor percentile rank dilakukan perbandingan hasil penilaian pengguna secara umum sedangkan pada Acceptability, grade scale, adjective rating dibedakan kedalam tiga kategori. Untuk itu dalam menentukan SUS skor percentile rank seperti ketentuan sebagai berikut:

a) Grade $A$ : dengan skor lebih besar atau sama dengan 80,3 b) Grade $B$ : dengan skor lebih besar sama dengan 74 dan lebih kecil 80,3

c) Grade $C$ : dengan skor lebih besar 68 dan lebih kecil 74.

d) Grade $D$ : dengan skor lebih besar sama dengan 51 dan lebih kecil 68.

e) Grade $F$ : dengan skor lebih kecil dari 51.

Berdasarkan ketentuan penentuan hasil penilaian SUS skor maka hasil penilaian responden terhadapat perangkat lunak Palembang Guide sebesar 83 (delapan puluh tiga) berada pada grade A.sehingga perangkat lunak Palembang Guide dapat dijadikan sebagai alat pendukung penyedia informasi sarana pendukung pelaksanaan Asia Games seperti venue olahraga, transportasi, objek wisata, restoran, toko (mall), hotel, tempat pengisian bahan bakar, fasilitas kesehatan, pos kemanan, kantor dan institusi pendidikan.

Dari dua proses penentuan hasil penelitian yang telah dilakukan baik secara Acceptability, grade scale, adjective rating maupun secara SUS skor percentile rank dapat dilihat perbedaan dari hasil akhir penilaian. Kondisi tersebut disebabkan adanya perbedaan sudut pandang dalam proses penentuan hasil penialain. Penentuan pertama dilakukan berdasarkan Acceptability, grade scale, adjective rating dimana satu sama lain berkaitan sedangkan SUS skor percentile rank hanya melihat dari sisi rank. Namun secara umum hasil penilaian reponden terhadap antarmuka perangkat lunak Palembang Guide dapat dikatakan baik atau dapat dimanfaatkan oleh pengguna akhir.

\section{KESIMPULAN}

SUS dapat dijadikan sebagai alat evaluasi penilaian antarmuka perangkat lunak yang terukur dan terstruktur secara akurat. memiliki beragam cara dalam menentukan hasil evaluasi penialai seperti yang diperlihatkan ketika melakukan evaluasi penilaian perangkat lunak Palembang Guide. Dari hasil evaluasi penilaian yang dilakukan terhadap perangkat lunak Palembang Guide mendapatkan skor 83 yang berarti perangkat lunak Palembang Guide dinyatakan acceptable termasuk dalam grade $\mathrm{A}$ dan $\mathrm{B}$ dengan 
rating excellent, sehingga antamuka perangkat lunak Palembang Guide layak untuk digunakan oleh pengguna akhir sebagai media alat bantu dalam mencari tempat-tempat sarana prasarana pendukung pelaksanaan Asian Games XVIII.

\section{DAFTAR PUSTAKA}

Asmani, J. M. (2011). Buku Panduan Internalisasi Pendidikan Karakter di Sekolah. Yogyakarta: Diva Press.

Bangor, A., Kortum, P. T., \& Miller, J. (2009). Determining what individual SUS scores mean: Adding an adjective rating scale. Journal of usability studies , 114-123.

Brooke, J. (1996). SUS - A quick and dirty usability scale. United Kingdom: Redhatch Consulting Ltd.

Brooke, J. (2013). SUS: A Retrospective. Journal of Usability Studies , 29-40.

Hadi, H. P. (2010). Usability engineering on IPB public relationship information system. Bogor: Departemen Ilmu Komputer Institut Pertanian Bogor.
Martoyo, W. U., \& Falahah. (2015). Kajian Evaluasi Usability dan Utility pada Situs Web. Seminar Nasional Sistem Informasi Indonesia (pp. 537543). Surabaya: Institut Teknologi Sepuluh November.

Mustami, M. K. (2016). Metode Penelitian Pendidikan. Yogyakarta: Aynat Publishing.

Pudjoatmodjo, B., \& Wijaya, R. (2016). Tes Kegunaan (Usabilty Testing) Pada Aplikasi Kepegawaian Dengan Menggunakan System Usabilty Scale (Studi Kasus: Dinas Pertanian Kabupaten Bandung). Semnasteknomedia (pp. 2-9). Yogyakarta: STIMIK Amikom.

Sauro, J. (2011). A Practical Guide to the System Usability Scale: Background, Benchmarks \& Best Practices. North Charleston SC: Create Space Independent Publishing Platform. 